\title{
Új adatok a magyar serdülőkorúak egészséget befolyásoló szokásairól és egészségi állapotáról
}

\author{
New data on the Hungarian adolescents' health related behaviours \\ and health status
}

Szerző: Németh Ágnes $\square$

Eötvös Loránd Tudományegyetem, Pedagógiai és Pszichológiai Kar, Pszichológiai Intézet

Beküldve: 2020. 01. 29.

doi: 10.24365/ef.v61i1.561

Kulcsszavak: HBSC; egészség; egészségmagatartás; szerfogyasztás; serdülő

Keywords: HBSC; health; health behaviour; substance use; adolescent

Tavaly decemberben jelent meg az Iskoláskorú gyermekek egészségmagatartása (Health Behaviour inSchool-aged Children, HBSC) elnevezésú, az Egészségügyi Világszervezettel (WHO) együttműködésben megvalósuló nemzetközi kutatás legújabb hazai vizsgálatának kutatási jelentése.

A felmérést és a tanulmányt az ELTE PPK Pszichológiai Intézetének HBSC Kutatócsoportja készítette.

A Kamaszéletmód Magyarországoncímű kötetet mely a L'Harmattan Kiadó gondozásában jelent meg - 2020. január 14-én az ELTE PPK aulájában sajtótájékoztató keretében mutatta be a kutatócsoport a szakmai közönségnek és a médiának. Prof. Dr. Demetrovics Zsolt, az ELTE PPK dékánjának és Dr. Ledia Lazëri, a WHO Magyarországi Iroda vezetőjének beszédei után Dr. Németh Ágnes kutatásvezető, valamint Várnai Dóra és Horváth Zsolt, a kötet szerzői mutatták be a kutatást és annak néhány fontosabb eredményét.

A standard nemzetközi módszertan szerint folyó kutatásban négyévenként kerül sor felmérésre az 5., a 7., a 9. és 11. évfolyamos diákok országosan reprezentatív mintáján. A tanulók az adatgyújtés során névtelenül, önkéntesen, szülői beleegyezéssel töltik ki a kérdőíveket. A legutóbbi, 2018-ban mintegy 6000 fö részvételével elvégzett adatfelvétel már a 9. alkalom volt hazánkban. Az eredmények átfogó képet adnak a felső tagozatos és középiskolás diákok egészséget befolyásoló szokásairól: többek között táplálkozásukról, fizikai aktivitásukról, dohányzási, alkohol- és drogfogyasztási szokásaikról, szexuális magatartásukról, társas kapcsolataikról (ezen belül kiemelten az elektronikusmédiakommunikációról), szubjektív egészségi állapotukról és közérzetükről.

Az eredmények sokfélék: kedvezőtlen és kedvező változásokat, valamint stagnálást egyaránt megfigyelhetünk a fiatalok egészségi és egészségmagatartási mutatóiban a négy évvel korábbi adatokhoz képest. Az étkezési szokásokkal kapcsolatban a kutatás arra világított rá, hogy a gyümölcsök és zöldségek napi fogyasztási arányainak 2000 óta javuló tendenciájában megtorpanás történt: jelenleg a kamaszoknak kevesebb, mint harmadára jellemző, hogy minden nap eszik gyümölcsöt, illetve zöldséget, és ez 3-4\%-kal alacsonyabb, mint négy éve. A minden tanítási napon reggelizők aránya még jelentősebb-mintegy 6\%-os - csökkenést mutat, és ez már statisztikai értelemben is jelentősnek mondható. Bár a napi édességfogyasztási arányok is 6\%-kal csökkentek, a túlsúlyosak aránya így is 5-6\%-os növekedést mutat, jelenleg átlagosan 23\% körüli. Ez utóbbi változás azért is említésre méltó, mert a 2000-2014 közötti időszakban 15-18\% körül ingadozott ennek a mutatónak az értéke. 
A fizikai aktivitás tekintetében a 2000 óta tartó határozott pozitív tendenciában szintén megtorpanást láthatunk. Itt meglehetősen markáns nemi eltérést is tapasztalunk: 2014 óta a minden nap elegendő mozgást végző (legalább 60 perc, legalább közepes intenzitással) fiúk aránya jelentős csökkenést mutatott, míg a lányoknál folyatódott az enyhén felfelé ívelő irányvonal. Összességében a 11-17 éves korosztálynak kevesebb, mint ötödéről mondható el, hogy az életkoruk alapján ajánlott fizikai aktivitás-szintet elérik.

Az egészséget veszélyeztető magatartási formák közül a szerfogyasztási arányok a korábbiakhoz hasonlóan alakultak: minden nyolcadik kamasz legalább hetente egyszer rágyújt, tízből négyen fogyasztottak alkoholt a kérdezést megelőző egy hónapban, és a középiskolások közül minden negyedik kipróbált már valamilyen drogot élete során. Ugyanakkor a lerészegedés előfordulása némi csökkenést mutat, bár az arányok még mindig magasak: az 5-11. évfolyamon tanulók több mint harmada volt már részeg életében. A középiskolás diákoknak átlagosan 43\%-a aktív szexuálisan. Ez az arány 2014-ig emelkedő volt, ehhez képest most nem tapasztaltunk változást, de meg kell jegyeznünk, hogy hazánkban európai viszonylatban kiemelkedően magas a szexuális kapcsolatot már létesített 15-17 évesek hányada. Emellett a szexuálisan aktív fiatalok ötöde arról számolt be, hogy semmilyen módon nem védekezett a legutóbbi szexuális együttlét alkalmával.

Az elmúlt négy évben romlott az egészségi állapot megítélése a magyar tinédzserek körében: négyből egy diák nem tartja jónak az egészségét. Magas a különböző testi-lelki tüneteket (fáradtságot, ingerlékenységet, rosszkedvet, idegességet) rendszeresen tapasztalók aránya, különösen a lányok körében. Tíz diákból három számolt be különböző hangulati problémákról, depresszív érzésekről.

A kutatási jelentés megvásárolható a könyvesboltokban, illetve elektronikus formában elérhető az ELTE PPK HBSC kutatócsoportjánál. 